\title{
Define Colony Number of Subterranean Termites Coptotermes gestroi (Isoptera: Rhinotermitidae) in Selected Infested Structures
}

(Penetapan Jumlah Koloni Anai-Anai Bawah Tanah Coptotermes gestroi (Isoptera:Rhinotermitidae) yang Menyerang Struktur Bangunan Terpilih)

\author{
AbDul Hafiz Ab MaJID* \& ABU Hassan AhMAD
}

\begin{abstract}
Termites are one of the social insects living in large colonies that can cause economic loss. The objective of this study was to estimate foraging territory of infested subterranean termites on building structure. A mark-recapture study was conducted on eight Coptotermes gestroi colonies located at selected infested building structures in Penang, Malaysia. From the foraging study, the population of C. gestroi was estimated to be within the range of 106,592 $\pm 6,968$ to 4,185,000 $\pm 2,127,328$. Additionally, the foraging territory was from 13 to $300 \mathrm{~m}^{2}$ of the infested building structures. Meanwhile the maximum foraging distance was from 4 to 30 m of the infested structures. The results indicated that each of the building structures was infested by a single colony. This study also showed that the triple mark recapture technique used to estimate the population size of the termite colony was capable of providing rough estimates of foraging population of $\mathrm{C}$. gestroi.
\end{abstract}

Keywords: Coptotermes gestroi; foraging distance; foraging population; foraging territories; triple mark recapture

ABSTRAK

Anai-anai adalah salah suatu serangga sosial yang hidup di dalam koloni besar yang boleh menyebabkan kerugian ekonomi. Objektif kajian ini adalah untuk menganggarkan wilayah keluasan mencari makanan anai-anai bawah tanah pada struktur bangunan. Suatu kajian tanda tangkap dan lepas semula telah dijalankan ke atas lapan koloni Coptotermes gestroi yang menyerang bangunan terpilih di Pulau Pinang, Malaysia. Daripada kajian mencari makanan, populasi

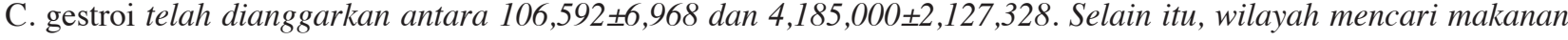
adalah dari 13 hingga $300 \mathrm{~m}^{2}$. Sementara itu, jarak maksimum linear mencari makanan adalah dari 4 hingga $30 \mathrm{~m}$. Keputusan kajian menunjukkan bahawa setiap struktur bangunan telah diserang oleh satu populasi anai-anai. Kajian ini juga menunjukkan bahawa tangkap-tanda dan lepas sebanyak tiga kali yang digunakan untuk membuat anggaran saiz koloni anai-anai mampu menyediakan anggaran kasar populasi mencari makanan oleh C. gestroi.

Kata kunci: Coptotermes gestroi; jarak mencari makanan; keluasan mencari makanan; saiz populasi; tangkap tiga kali bertanda

\section{INTRODUCTION}

Foraging and population territory studies are important to determine the termite population and foraging size in order to achieve effective termite control. Foraging population of subterranean termite can be estimated using two methods, mark recapture and direct counting. However, none of these methods have been absolutely accurate, although mark recapture is generally more acceptable because of its practicality for studying termite populations in the field (Nutting \& Jones 1990).

Two mark- recapture methods that have been used intensively to estimate the foraging populations of subterranean termites are single mark recapture and triple-mark recapture techniques. The single mark recapture technique with Lincoln Index (Begon 1979) was used to estimate the foraging populations of Coptotermes formosanus Shiraki (Lai 1977; Su et al. 1984), Reticulitermes spp. (Forschler \& Townsend 1996a),
Globitermes sulphureus Haviland (Abdul Hafiz et al. 2008; Abdul Hafiz \& Abu Hassan 2007; Lee et al. 2003a; Ngee \& Lee 2002). The triple mark recapture technique using weighted mean method (Begon 1979) was used to estimate the populations of C.formosanus (Su \& Scheffrahn 1988), Reticulitermes flavipes Kollar (Forschler \& Townsend 1996b; Su et al. 1993), Reticulitermes speratus Kolbe (Tsunoda et al. 1998), Coptotermes gestroi Wasmann (Sornnuwat et al. 1996), Coptotermes curvignathus Wasmann (Abdul Hafiz \& Abu Hassan 2006; Sajap 1999) and Microtermes pakistanicus Ahmad (Lee et al. 2003b). In this study, triple mark recapture technique was used because it increases the ratio of recaptured termites in the population as compared to single mark recapture with Lincoln Index on (Begon 1979).

Mark-recapture techniques have been used to estimate the foraging territories of the subterranean termites. Several different markers have been used in previous works. Lai 
(1977) pioneered the use of histological dyes that have been adopted by other termite researchers (Evans et al. 1998; Haagasma \& Rust 1993; Lai et al. 1983; Su et al. 1983). Spragg and Paton (1980) used radio isotope to trace the foraging territories of subterranean termites. Forschler (1994) and Miller (1993) used fluorescent paint. Other methods to estimate foraging territory include using direct counts of fumigated mounts (Darlington 1984), agonistic behavior of subterranean termites (Jones 1990; Pearce 1997) and direct excavation (Howard et al. 1982). In this study, Nile Blue A was used as markers. Nile Blue A is a type of stain used in the mark-recapture study to determine the efficiency of recapturing. It was chosen for marking the termites because the stain could last longer in the field (Haagasma \& Rust 1993). Ngee and Lee (2002) found that the blue stained Globitermes sulphureus could remain blue as long as 60 days in the laboratory. At present, in Malaysia, Abdul Hafiz et al. (2007), Lee (2001), Lee et al. (2003b) and Sajap et al. (2000) had used Nile Blue A to estimate the termite foraging population of $C$. gestroi, C.curvignathus and G. sulphureus. Abdul Hafiz et al. (2007) discovered that the blue stain could last for 90 days in the field studies for G. sulphureus. The objectives of this paper were to identify the foraging distances and population territories of subterranean termites (C.gestroi) in selected structures of Penang, Malaysia.

\section{MATERIALS AND METHODS}

\section{STUDY SITES AND TERMITE MONITORING STATION SETUP}

Eight $C$. gestroi sites in Penang, Malaysia, were chosen for this study (Table 1). There were two types of termite monitoring stations - the above ground and the underground monitoring stations. Pre-installations of stations and pine wood billets similar to those described by $\mathrm{Su}$ and Scheffrahn (1988) were installed in the ground within the range of 1.5 to $3 \mathrm{~m}$ apart around buildings/structures. 100-300 pine stakes were used for every study site. Termite feeding consumption was higher using those two species of pine wood, Pinus caribaea and Araucaria cunninghamii (Abdul Hafiz \& Abu Hassan 2007). Pine billets that were infested with termites were replaced with the in-ground monitoring stations. An in-ground monitoring station
(IG) consisted of a hollow plastic container $(20 \mathrm{~cm}$ in diameter by $19 \mathrm{~cm}$ in height) and a bundle of nine pine stakes, oven-dried for $48 \mathrm{~h}$ at $80^{\circ} \mathrm{C}$, cooled on a tray and placed in the bucket. The buckets were buried at a depth of approximately $2.5 \mathrm{~cm}$ below the level of the ground. The in-ground monitoring stations were inspected biweekly to observe termite feeding activities. The above ground monitoring stations $(\mathrm{AG})$ were black plastic boxes $(6 \times 11 \times 6$ $\mathrm{cm})$. The box was painted black to minimize evaporation of moisture inside the box (Mohd Yusri et al. 2005). Two sets of rolled toilet tissue paper weighing between 40-80 $\mathrm{g}$ and oven-dried for $48 \mathrm{~h}$ at $50^{\circ} \mathrm{C}$, were placed inside the box. The boxes were installed with overactive termite mud tubes. 10-20 boxes were used per-site. The above ground monitoring stations were examined every two weeks to observe termite feeding activities.

\section{ESTIMATION OF TERMITE POPULATION AND FORAGING RANGE}

After the establishment of $\geq 2$ monitoring stations per site, a mark recapture program was carried out to estimate the foraging territory and the population size of the termites. The infested blocks from the in-ground monitoring stations were taken to the laboratory and carefully disassembled. The termites were removed by gently tapping the stakes over a plastic tray. They were separated from debris by allowing them access to a stack of five pine blocks $(20 \times 10$ $\mathrm{cm}$ ) that had been soaked in water for $24 \mathrm{~h}$. After a 4-6 $\mathrm{h}$ aggregation on pine blocks, they were removed. The mean body weight of the termite workers was determined by weighing five groups of 10 individuals. The numbers of collected workers were determined by the total weight of collected workers and the mean worker weight to estimate the total of termites that were collected from the monitoring stations (Tamashiro et al. 1973). The termite workers collected from a station with a heavy feeding activity were stained with $0.1 \%$ (wt/wt) Nile Blue A by a no choice feeding of stained filter paper (Whatman No. 1, $9.0 \mathrm{~cm}$ in diameter) for 5 days (Su et al. 1991). The stained termites were released into the same station where they were collected. The total number of stained termites released depended on the total number of termites recaptured from the active monitoring station and it varied

TABLE 1. Locations and type of buildings infested by C. gestroi

\begin{tabular}{lllcc}
\hline Site & Location & Type of building & $\begin{array}{c}\text { Number of in- } \\
\text { ground station }\end{array}$ & $\begin{array}{c}\text { Number of above- } \\
\text { ground station }\end{array}$ \\
\hline 1 & Bayan Baru & Double story terrace & 0 & 6 \\
2 & Mengkuang & Single story bungalow & 3 & 0 \\
3 & Gelugor & Double story bungalow & 4 & 2 \\
4 & Guar Perahu & Wooden double story Malaysia traditional house & 3 & 3 \\
5 & Bayan Lepas & Single story bungalow & 0 & 3 \\
6 & Taman Rupawan & Single story bungalow & 3 & 0 \\
7 & Islamic Centre, USM & A mosque & 13 & 0 \\
8 & Plant house, USM & Greenhouse & 7 & 3 \\
\hline
\end{tabular}


for every study site. The monitoring stations at each site were checked 7 days after the release to record the number stained termites recaptured from the monitoring stations for that cycle (Su et al. 1991). The mark-released-recapture cycle was repeated for three rounds. Each round was run for two weeks. The foraging territory of a colony was defined as the area encompassed by the stations containing termites during the triple mark recapture cycles (TMR) ( $\mathrm{Su} \&$ Scheffrahn 1988). Meanwhile, the linear foraging distance was measured from one of the active monitoring stations containing blue termites to the furthest away monitoring station that contain blue termites at a site.

\section{DATA ANALYSIS}

The number of marked and unmarked workers was recorded for each cycle. A mean weight model (Begon 1979; Su et al. 1993) was used to estimate the foraging population $(\mathrm{N})$ and the associated standard error (SE);

$$
\begin{aligned}
& \mathrm{N}=\left(\sum \operatorname{Min} i /\left[\sum \mathrm{m} i\right)+1\right] \\
& \mathrm{SE}=N \sqrt{\left[1 /\left(\sum m i+1\right)\right]+\left[2 /\left(\sum m i+1\right)^{2}\right]+\left[6 /\left(\sum m i+1\right)^{3}\right.}
\end{aligned}
$$

where $\mathrm{N}$ is the mean foraging population; $\mathrm{SE}$ is the associated standard error for the $i$ th cycle; $m i$ is the total number of marked individuals up to the $i$ th cycle; $M i$ is the number of marked individuals among the captured termites and $\mathrm{n} i$ is the number captured.

\section{RESULTS AND DISCUSSION}

The triple mark recapture (TMR) method is widely used by termite researchers to estimate the foraging population of $C$. formasanus and $R$. flavipes (DeMark et al. 1995; Su et al. 1991). In Malaysia, triple mark recapture was used by Abdul Hafiz and Abu Hassan (2006) and Sajap et al. (2000) to estimate the foraging population of $C$. curvignathus and by Lee (2001) to estimate the foraging population of C. gestroi.

Our results showed that $C$. gestroi population in Penang, Malaysia was in the range of $56,127 \pm 11,925$ and 4,185,000 $\pm 2,127,328$ at the eight sites (Table 2). Meanwhile in Thailand, $C$. gestroi population was smaller ranging from 1.13 to $2.75 \times 10^{6}$ (Sornnuwat et al. 1996). Sajap et al. (2000) reported that the foraging population of $C$. curvignathus was in the range from 1.6 to $7.1 \times 10^{5}$ with the foraging territory between 15 and $50 \mathrm{~m}^{2}$ (Table 3 ).

The Malaysian population colonies of Coptotermes are smaller compared with the other Coptotermes species found outside Malaysia, such as C. formasanus. The population of $C$.formasanus was estimated in the range of 1.8 to $4.4 \times 10^{6}$ (Su et al. 1984 ), from 1.05 to $2.24 \times 10^{6}$ with the foraging territory was between 143 and $2189 \mathrm{~m}^{2}(\mathrm{Su}$ et al. 1984). The population estimation for Reticulitermes flavipes was even larger ranging from 4 to $19.1 \times 10^{6}$ (Grace et al. 1989; Haverty et al. 1999) in the United States.
The termite foraging population varies according to species. According to Lee et al. (2003a), the population estimate for M.pakistanicus was from 1.07 to $5.59 \times 10^{5}$ and consisted of five different colonies, with a foraging territory of $30.5-54.2 \mathrm{~m}^{2}$. As for G. sulphureus, the foraging population was between 5.14 and $8.69 \times 10^{5}$ and consisted of three different colonies with a foraging territory of 5.9-42.5 $\mathrm{m}^{2}$ (Lee et al. 2003b). In addition, by using Lincoln Index, Abdul Hafiz et al. (2007) estimated that the foraging population of $G$. sulphureus was $3.38 \times$ $10^{5}$ with the foraging territory of $96 \mathrm{~m}^{2}$.

Environmental factors of soil characteristics such as $\mathrm{pH}$, moisture, temperature, the presence of microorganism, organic materials (Chapman et al. 1982; Felsot 1989; Harris 1972; Macalady \& Wolfe 1983; Tashiro \& Kuhr 1978) and soil type (Campbell et al. 1971; Forschler \& Townsend 1996a, 1996b; Harris 1972; Lange \& Carlson 1956; Smith \& Rust 1993) could also affect the foraging territory and estimated population of termites. Therefore, further study need to be carried to determine if soil types influence the foraging behavior of subterranean termites.

Site 8 (Plant House) had a larger foraging population size maybe due to the site being an open site where the colony was undisturbed by human activities. Site 5 (Bayan Lepas) had the smallest foraging population size, probably due to the size of the house and the colony was just below the house where human activities could have disturbed the foraging activities of the termites (Vasconcellos et al. 2010). Furthermore, it is possible that the age of termite colonies might be the reason of finding larger or smaller colonies in some places than others. Maybe, the smaller colonies are newly established colonies, while the larger ones have been in the area for a long time (Husseneder 2005; Vasconcellos et al. 2010).

The termite foraging behavior still requires more intensive and detail research. Owing to their epigeic foraging habits, ecologically prominent and abundant termites such as Macrotermes, Schedorhinotermes, Hospitalitermes and Nasutitermes would be excellent models for the study of the social organization and the divisions of labor that appear to enhance the efficiency of food collection. According to Reinhard et al. (1997), the efficiency of foraging and the addictiveness of the caste distributions that participate in different aspects of foraging have rarely been measured. In addition, knowing the population size and foraging territory of subterranean termites will help us determine how much termiticides is required to suppress the population. Therefore, less chemical usage could be applied to manage subterranean termite infestation inside the building structure.

\section{CONCLUSION}

This study showed the foraging population for $C$. gestroi was estimated to be between 106,592 $\pm 6,968$ and $4,185,000 \pm 2,127,328$ individual number of foraging termite per colony with the foraging territory between 13 and $300 \mathrm{~m}^{2}$ and the linear foraging distance between 5 and 
TABLE 2. Triple mark recapture cycles, underground monitoring station, above-ground monitoring station [ ]. The number in the bracket indicates the monitoring station number where the marked termites were found in each cycle

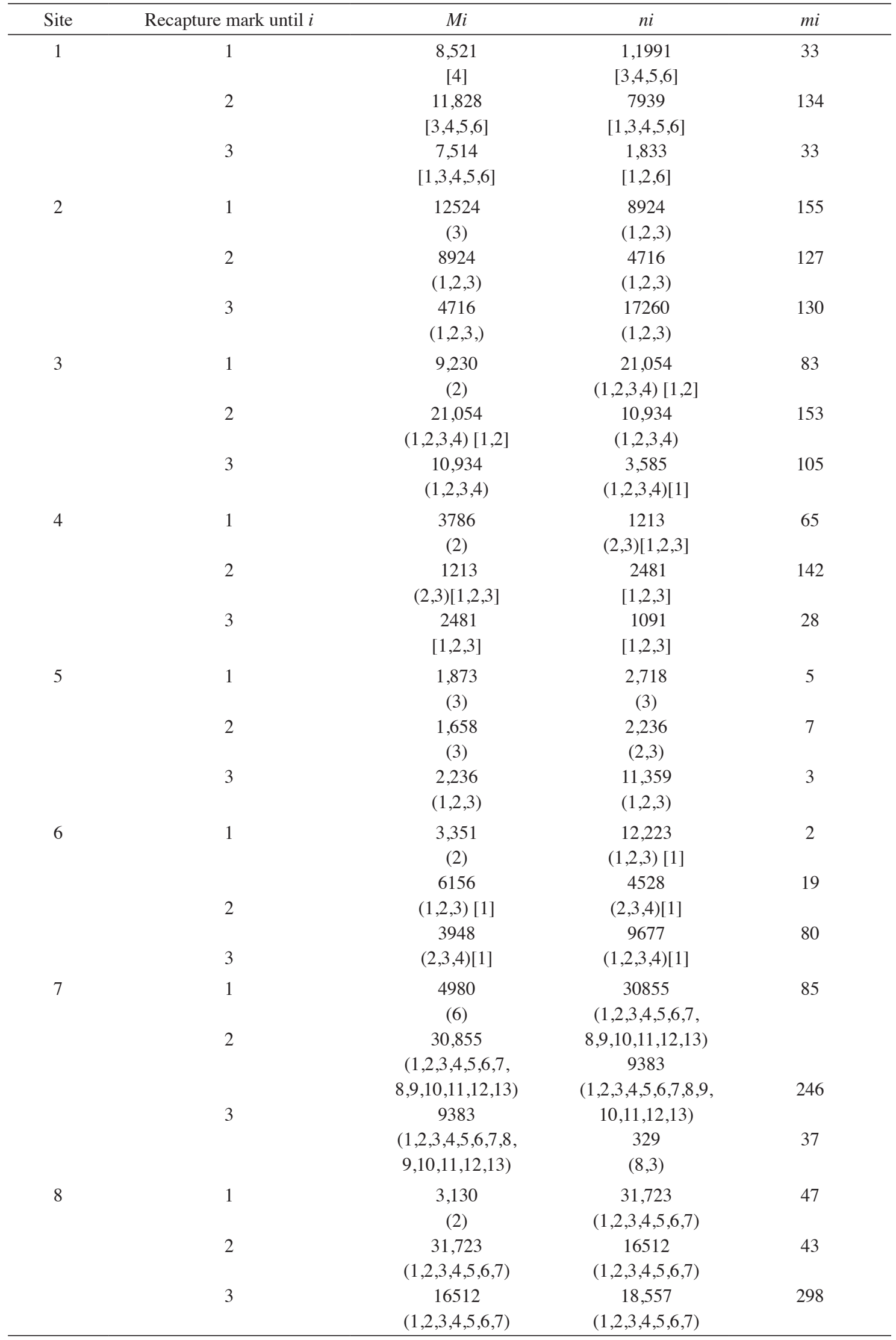

for each $i$ th cycle, $M i=$ total number of marked individuals up to the $i$ th cycle; $m i=$ number of marked individuals among captured termites; and $\mathrm{n} i=$ the number of termites captured 
TABLE 3. Foraging population, foraging territory and linear foraging distance of C. gestroi

\begin{tabular}{clccc}
\hline Site & Location & $\begin{array}{c}\text { Population } \pm \text { standard error } \\
(\mathrm{N} \pm \mathrm{SE})\end{array}$ & $\begin{array}{c}\text { Foraging territory } \\
\left(\mathrm{m}^{2}\right)\end{array}$ & $\begin{array}{c}\text { Linear foraging distance } \\
(\mathrm{m})\end{array}$ \\
\hline 1 & Bayan Baru & $1,566,164 \pm 111,017$ & 40 & 5 \\
2 & Mengkuang & $1,608,967 \pm 79364$ & 40 & 15 \\
3 & Gelugor & $1,974,252 \pm 107,224$ & 257 & 18 \\
4 & Kg.Guar Perahu & $106,592 \pm 6,968$ & 20 & 4 \\
5 & Bayan Lepas & $1,559,181 \pm 412,641$ & 13 & 6 \\
6 & Taman Rupawan & $2,108,986 \pm 210,858$ & 257 & 28 \\
7 & Islamic Centre USM & $1,367,952 \pm 71,405$ & 300 & 30 \\
8 & Plant House, USM & $4,185,0026 \pm 2127328$ & 216 & 24 \\
\hline
\end{tabular}

$30 \mathrm{~m}$. Each of the building structures was only infested with single termite colony. This study also showed that the triple mark recapture technique used to estimate the population size of the termite colony was capable of providing rough estimates of foraging population of $C$. gestroi.

\section{ACKNOWLEDGEMENTS}

The authors would like to thank Universiti Sains Malaysia for funding the research (Research University Grant (RU) (1001/PBIOLOGI/811241). We would also like to thank the School of Biological Sciences, Universiti Sains Malaysia (USM) for the facilities provided for conducting the research. Thanks to Dr Xing Ping Hu from Auburn University for reviewing the manuscripts. We thank Mr. Hadzri Abdullah for his technical assistance and the homeowners for allowing us to access their properties to conduct the experiment.

\section{REFERENCES}

Abdul Hafiz, A.M. \&. Abu Hassan, A. 2007. Comparison of subterranenan termite feeding preference, Coptotermes curvignathus (Isoptera: Rhinotermitidae) towards two different malaysia softwood species Pinus caribaea and Araucaria cunninghamii in the field. Malaysian Applied Biology 36: 75-77.

Abdul Hafiz, A.M. \& Abu Hassan, A. 2006. Control of subterranean termites Coptotermes curvignathus (Isoptera: Rhinotermitidae) by baiting technology in the School of Biological Sciences, Universiti Sains Malaysia, Penang Malysia. Paper presentation at International Conference on Science and Technology, Universiti Teknologi MARA, December 8-10 (abstract only) Penang, Malaysia. p. 54.

Abdul Hafiz, A.M., Abu Hassan, A. \& Rashid, M.Z.A. 2008. Field efficacy of imidacloprid against Coptotermes gestroi (Isoptera: Rhinotermitidae) and Globitermes sulphureus (Isoptera: Termitidae) in Seberang Perai and Balik Pulau, Penang, Malaysia. Malaysian Applied Biology 37: 19-23.

Abdul Hafiz, A.M., Abu Hassan, A., Rashid, M.Z.A. \& Che Salmah, M.R. 2007. Field efficacy of imidacloprid on Globitermes sulphureus (Isoptera:Termitidae) (subterranean termite) in Penang. Tropical Life Science Research 18: 109114.

Begon, M. 1979. Investigating Animal Abundance: Capturerecapture for Biologists. Baltimore, MD: University Park Press. p. 97.
Campbell, W.V., Mount, D.A. \& Heming, B.S. 1971. Influence of organic matter content of soils on insecticidal control of the wireworm Melanotus communis. Journal Economic Entomology 64: 41-44.

Chapman, R.A., Tu, C.M. \& Harris, C.R. 1982. Biochemical and chemicalformations of phorate, phorate sulfoxide and phorate sulfone in natural and steril mineral organic soils. Journal Economic Entomology 75: 112-117.

Darlington, J.P.E.C. 1984. A method for sampling the population of large termite nest. Annals of Applied Biologists 104: 427-436.

DeMark, J.J., Benson, E.P., Zungoli, P.A. \& Kard, B.M. 1995. Evaluation of hexaflumuron for termite control in the southeast U.S. Down to Earth 50: 20-26.

Evans, T.A., Lenz, M. \& Gleeson, P.V. 1998. Testing assumptions of mark-recapture protocols for estimating population size, using Australian mound-building, subterranean termites. Ecological Entomology 23: 139-159.

Felsot, A.S. 1989. Enhanced biodegradation of insecticides in soil: Implications for agroecosystems. Annual Review Entomology 34: 453-476.

Forschler, B.T. 1994. Survivorship and tunnelling activity of Reticulitermes flavipes (Kollar) (Isoptera: Rhinotermitidae) in response to termiticide soil barriers with and without gaps of untreated soil. Journal Entomological Science 29: 43-54.

Forschler, B.T. \& Townsend, M.L. 1996a. Mark-releaserecapture estimates of Reticulitermes spp. (Isoptera: Rhinotermitidae) colony foraging populations from Georgia, USA. Environmental Entomology 25: 952-962.

Forschler, B.T. \& Townsend, M.L. 1996b. Mortality of eastern subterranean termites (Isoptera: Rhinotermitidae) exposed to four soils treated with termiticides. Journal of Economic Entomology 89: 678-681.

Grace, J.K.,Abdallay, A. \& Farr, K.R. 1989. Eastern subterranean termite (Isoptera: Rhinotermitidae) foraging territories and populations in Toronto. The Canadian Entomologist 121: 551-556.

Haagsma, K.A. \& Rust, M.K. 1993. Two marking dyes useful for monitoring field populations of Reticulitermes hesperus (Isoptera: Rhinotermitidae). Sociobiology 23: 155-164.

Harris, C.R. 1972. Factors influencing the effectiveness of soil insecticides. Annual Review Entomolology 37: 103-113.

Haverty, M.I., Getty, G.M., Copren, K.A. \& Lewis, V.R. 1999. Seasonal foraging and feeding behavior of Reticulitermes spp. (Isoptera: Rhinotermitidae) in a wildland and residential location in northern California. Environmental Entomology 28: 1077-1084.

Howard, R.W., Jones, S.C., Mauldin, K. \& Beal, R.H. 1982. Abundance, distribution, and colony size estimates for 
Reticulitermes spp. (Isoptera: Rhinotermitidae) in southern Mississippi. Environmental Entomology 11: 1290-1293.

Husseneder, C., Messenger, M.T., Su, N.Y., Grace, J.K. \& Vargo,E.L. 2005. Colony social organization and population genetic structure of an introduced population of Formosan subterranean termite from New Orleans, Louisiana. Journal of Economic Entomology 95(5): 1421-1435.

Jones, S.C. 1990. Delineation of Heterotermes aureus (Isoptera: Rhinotermitidae) foraging territories in a Sonoran desert grassland. Environmental Entomology 19: 1047-1054.

Lai, P.Y. 1977. Biology and ecology of the formosan subterranean termite, Coptoterrnes formosanus and its susceptibility to the entomogenus fungi, Beauveria bassiana and Metarrhiziuni anisopliae. PhD Thesis. University of Hawaii. p.140 (summary only) (unpublished).

Lai, P.Y., Tamashiro, M., Fuji, J.K., Yates, J.R. \& Su, N.Y. 1983. Sudan Red 7B, a dye marker for Coptotermes formosanus. Proceedings of Hawaii Entomology Society 24: 277-282.

Lange, W.H. \& Carlson, E.C. 1956. Residual soil insecticides for the control of wireworms affecting vegetable crops. Hilgardia 26: 62-75.

Lee, C.Y.2001. Foraging populations and control of Coptotermes travians (Haviland) using hexaflumuron baits in Malaysia. Proceedings of the 2nd International Symposium on Coptotermes formosanus. May 13-15. New Orleans, United State of America.

Lee, C.Y., Yap, J., Ngee, P.S. \& Zairi, J. 2003a. Foraging colonies of a higher mound-building subterranean termite, Globitermes sulphureus (Haviland) in Malaysia. Japanese Journal of Environmental Entomology and Zoology 14: 105-112.

Lee, C.Y., Yap, J., Ngee,P.S. \& Zairi, J. 2003b.Foraging populations and territories of moundbuilding subterranean termite, Microtermes pakistanicus (Isoptera: Macrotermitinae). Sociobiology 41: 307-316.

Macalady, D.L. \& Wolfe, N.L. 1983. New perspectives on the hydrolytic degradation of the organophosphorothoate insecticide chlorpyrifos. Journal of Agricultural Food Chemistry 31: 1139-1147.

Miller, L.R. 1993. Fluorescent dyes as markers in studies of foraging biology of termite colonies. Sociobiology 23: 127-134.

Mohd Yusri, M.Y., Abu Hassan, A., Sajap, A.S., Che Salmah, M.R. \& Mat Amin, J. 2005. Subterranean termites from selected building premises in northern building premises in northern Peninsular Malaysia. Tropical Life Science Research 16: 63-74

Ngee, P.S. \& Lee, C.Y. 2002. Colony characterization of a moundbuilding subterranean termite, Globitermes sulphureus (Isoptera: Termitidae) using modified single mark recapture technique. Sociobiology 40: 525-532.

Nutting, W.L. \& Jones, S.C. 1990. Methods for studying the ecology of subterranean termites. Sociobiology 17: 167-189.

Pearce, M.J. 1997. Termites: Biology and Pest Management. Wallingford, U.K: CAB International.

Reinhard, J., Hertel, H. \& Kaib, M. 1997. Feeding stimulating signal in labial gland secretion of subterranean termite Reticulitermes santonesis. Journal of Chemical Ecology 3: 2371-2381.

Sajap, A.S. 1999. Detection of foraging activity of Coptotermes curvignathus (Isoptera: Rhinotermitidae) in an Hevea brasiliensis plantation in Malaysia. Sociobiology 33: 137143.
Sajap, A.S., Amit, S. \& Welker, J. 2000. Evaluation of hexaflumuron for controlling the subterranean termite Coptotermes curvignathus (Isoptera: Rhinotermitidae) in Malaysia. Journal of Economic Entomology 93: 429-433.

Smith, J.L. \& Rust, M.K. 1993. Cellulose and clay in sand affect termiticide treatments. Journal of Economic Entomology 86: 53-60

Sornnuwat, Y., Tsunoda, K., Yoshimura, Y., Takahashi, M. \& Vongkaluang, C. 1996. Foraging populations of Coptotermes gestroi (Jsoptera: Rhinotermitidae) in an urban area. Journal of Economic Entomology 89: 1485-1490.

Spragg, W.T. \& Paton, R. 1980. Tracing, trophallaxis and population measurement of colonies of subterranean termites (Isoptera) using a radioactive tracer. Annals Entomology Society of America 73: 708-714.

Su, N.Y. \& Scheffrahn, R.H. 1988. Foraging populations and territories of the Eastern subterranean termite (Isoptera: Rhinotermitidae) in an urban environment. Sociobiology 14: 353-359.

Su, N.Y., Ban, P.M. \& Scheffrahn, R.H. 1993. Foraging populations and territories of the eastern subterranean termite (Isoptera: Rhinotermitidae) in southeastern Florida. Environmental Entomology 22: 1113-1117.

Su, N.Y., Ban, P.M. \& Scheffrahn, R.H. 1991. Suppression of foraging population of the Formosan subterranean termite (Isoptera: Rhinotermitidae) by field applications of slowacting toxicant bait. Journal of Economic Entomology 84: $1525-1531$

Su, N.Y., Tamashiro, M., Yates, J.R., Lai, P.Y. \& Haverty, M.I. 1984. Foraging behavior of Formosan subterranean termite. Environmental Entomology 13: 1466-1470.

Su, N.Y., Tamashiro, M., Yates, J.R., Lai, P.Y. \& Haverty, M.I. 1983. A dye, Sudan Red 7B, as a marking material for the foraging studies with the Formosan subterranean termite. Sociobiology 8: 91-97.

Tamashiro, T., Fujii, J.K. \& Lai, P.Y. 1973. A simple method to observe, trap, and prepare large numbers of subterranean termites for laboratory and field experiments. Environmental Entomology 2: 721-722.

Tashiro, H. \& Kuhr, R.J. 1978. Some factors influencing the toxicity of soil applications of chlorpyrifos and diazinon to European chafer grubs. Journal of Economic Entomology 71: 904-907.

Tsunoda, K., Matsuoka, H. \& Yoshimura, T. 1998. Colony elimination of Reticulitermes speratus by bait application and the effect on foraging territory. Journal of Economic Entomology 91: 1383-1386.

Vasconcellos, A., Bandeira, A.G., Moura, M.S., Araujo, V.F.P., Gusmao, M.A.B. \& Constantino, R. 2010. Termite assemblages in three habitats under different disturbance regimes in the semi-arid Caatinga of NE Brazil. Journal of Arid Environments 74: 298-302.

Household \& Structural Urban Entomology Laboratory

School of Biological Sciences

Universiti Sains Malaysia

11800 Minden, Penang

Malaysia

*Corresponding author; email: abdhafiz@usm.my

Received: 14 November 2013

Accepted: 4 August 2014 